\title{
Silver fir (Abies alba Mill.) occurrence in south-eastern part of Ilżecka Forest
}

\author{
Ryszard Bis $^{1 凶}$, Dorota Dobrowolska ${ }^{2}$ \\ ${ }^{1}$ Forest Inspectorate Starachowice, ul. T. Krywki 14d, 27-200 Starachowice, Poland; \\ ${ }^{2}$ Forest Research Institute, Department of Forest Ecology, Sękocin Stary, ul. Braci Leśnej 3, 05-090 Raszyn, Poland. \\ Tel. +48 41 2745384, e-mail: Ryszard.Bis@wp.pl
}

\begin{abstract}
The study was conducted in Starachowice Forest District in Iłżecka Forest in southern part of Poland. Silver fir was the main tree species in Iłżecka Forests in the past. Nowadays the area is occupied by Scots pine forests, however the percentage of silver fir has recently increased again. The distribution of silver fir is uneven in this region. The article tries to answer the following questions: What does determine the distribution of silver fir stands in Iłżecka Forest? Do the geological conditions influence the occurrence of fir stands? The distribution of fir stands was investigated according to the main environmental parameters such as site types, soil types and underlying geology. The data on stand description were collected from management plans (period 1941-2005), general maps of the Starachowice Forest District and the Geological Map of Poland. The distribution of fir stands depended on forest site types. Soil type did not influence the occurrence of silver fir stands. Forests with silver fir were found both on Mesozoic rock from the Middle Jurassic period and on the strip next to the border separating Middle and the Upper Jurassic periods. More homogeneous fir areas were present on the geological bedrock from the Tertiary and the Middle Jurassic period rather than the Upper Jurassic, which may indicate that geological base substantially influenced fir expansion in the research area.
\end{abstract}

Key words: soil type; geological base; fir stands; forest site type

\section{Introduction}

The present range of silver fir (Abies alba Mill.) and its share in the species composition of forests is inseparably linked with the history of human economic activity dominated by economic objectives. Poland's contemporary vegetation was mostly formed in the last post-glacial period of plant community development, covering about 10.000 years. Fir appeared about 4.000 to 5.000 years ago in the mountains in the south of Poland, extending, along with beech, into the lower montane zone and showing further expansion northwards (Shepher 1959; Środoń 1983). Currently, forest stands in which fir is the dominant species occupy $2 \%$ of the forest area and have a $2.7 \%$ share in the volume in the forests managed by the State Forests. The average volume of forest stands with dominant fir is $318 \mathrm{~m}^{3} / \mathrm{ha}$, the largest of all the dominant tree species (compared with the volume of stands with dominant pine being $242 \mathrm{~m}^{3} / \mathrm{ha}$ ).

Almost the entire Iłżecka Forest is located in the Świętokrzyskie Province where stands with dominant pine cover an area of 161.642 ha, or $72.2 \%$ of its area. Fir is ranked the second dominant species covering 23.132 ha, or $10.3 \%$ of the forest area in the Province (PGLLP 2008).

Previous studies on silver fir were conducted primarily in the Świętokrzyski National Park and in adjacent forest stands located in the territory of the Forest Districts: Kielce, Łagów, Zagnańsk, Suchedniów and Skarżysko. The research focused on the role of silver fir as the main forest tree species in this area (Podlaski 2008), the cutting system (Bernadzki 1967, 1974; Bernadzki, Szeremetti 1976), the health condition

Received 17 February 2012, accepted after revision 07 May 2013.

(C) 2013, Forest Research Institute 
of fir (Graniczny, Dobrowolska 1990; Podlaski 2000; Dolnicki, Kuchciński 2003), the effect of soil properties on fir viability (Podlaski 2001), the technical properties of wood (Królicki 2004) and the radial growth of fir (Feliksik 1986; Feliksik et al. 2000). The principles of forest protection for the Świętokrzyska fir against damage from Tortrix spp. were also developed (Wiąckowski 1978).

Regeneration, advance growth and underwood of silver fir beneath the canopy of the prevailing pine forests appear in many fragments of the Iłżecka Forest. The proportion of fir in the upper storey (overstorey) of forest stands also increases. The existing stands with pine as a dominant species undergo natural transformation into mixed, two- and multi-storeyed, uneven-aged stands with fir, showing higher productivity and stability.

The distribution of fir stands in the Iłżecka Forest area is uneven. What are the causes of the present fir distribution? Can the local geological conditions determine the distribution of fir stands in the Forest? In an attempt to answer the above questions, an analysis of the fir occurrence area with regard to the type of forest habitat, soil subtype and the type of quaternary bedrock was carried out.

\section{Study area}

The research was conducted in the forests of the subdistricts: Kutery with an area of 1703.45 ha (1620.70 ha of forest area) and Klepacze with an area of 1912.78 ha (1802.06 ha of forest area) located within the administrative borders of 1932 . The total investigated site as on 01.10 .1932 amounted to 3616.23 ha. At present, these are forests situated in the sub-districts: Zawały (in part), Myszki (in part), Kutery and Klepacze, as part of the Lubien Forest Management Unit (Obręb) lying within the confines of the Starachowice Forest District. The total investigated site as at 01.01.2006 amounted to 3572.91 ha. According to the geographic distribution (regionalisation) of natural-forest regions, forest stands of the Iłżecka Forest are located in the Małopolska Region-VI and the Iłżecki Foothill mezoregion. The Iłżecki Foothill mezoregion (342.33) is located in the area of the Middle-Poland glaciation. The proportion of Scots pine as a dominant species in the composition of stands in this mezoregion is almost $20 \%$ higher compared with the stands in the Świętokrzyskie Mountains. The proportion of fir is nine times smaller and occurs on $2.2 \%$ of the Forest area, which is comparable to the national average (ORWLP 2004). On the basis of the physico-geographical regionalisation of Poland, the research area lies within the megaregion outside the West European Alpine region (3), Polish upland region (34), in the Małopolska Upland sub-region (342), Kielce Upland macroregion and Iłżecki Foothill mezoregion (342.33) (Kondracki 2000).

According to the climatic regionalisation of Poland, the research area is located in the Eastern Małopolska region. It is characterised by a relatively small number of moderately warm days (about 122 including 58 rainfall days). The hottest month is July, and the coldest is January. The maximal temperature is $+35 \mathrm{C}$, and the minimal is $-30 \mathrm{C}$. The average annual number of days with ground frosts range from 108 to 130 . The average length of the growing season is about 205 days (Woś 1999).

\section{Materials and methods}

The data used in this research were taken from the forest management plans for the Kutery and Klepacze Forest Sub-Districts within the administrative borders of 1932. The selected terms of stand description, such as compartment (stand), sub-compartment, compartment size, species composition of the upper (overstorey) and lower (understorey) storeys of stands, advance growth and underwood layers, stand density (stocking), site index, average age, height and diameter at breast height of dominant tree species, forest habitat type, soil sub-type and volume of merchantable timber were obtained from stand descriptions in the following forest management plans:

- Forest Management Plan for the period 1932/1933$1941 / 1942$ as on 01.10 .1932 for the Kutery and Klepacze Forest Sub-Districts, Klepacze Forest District.

- Forest Management Plan for the period $1941 / 1942-1950 / 1951$ as on 10.01 .1941 for the Kutery and Klepacze Forest Sub-Districts, Klepacze Forest District (for stands of the Kutery and Klepacze Forest Sub-Districts in the administrative borders of 1932).

- Forest Management Plan for the Starachowice Forest District, Lubien Forest Management Unit for the period 1996-2005, volume 3 (for stands of the Kutery and Klepacze Forest Sub-Districts in the administrative borders of 1932).

- Forest Management Plan for the Starachowice Forest District, Lubien Forest Management Unit for the period 2006-2015, Volume III (for stands of the Kutery and Klepacze Forest Sub-Districts in the administrative borders of 1932).

Also the following maps were used in the research: the pictorial map of 1932 of the Starachowice Forest District 
with a scale of 1:40,000, the general map of the Klepacze Forest District, as on 10.01.1941 and the forest digital map of the Starachowice Forest District as on 1.01.2006.

The share of the species by area in the composition of stands was assumed to be the ratio of forest stand/compartment area to the share of this species expressed in decimal numbers (e.g. $4 \mathrm{Jd}=0.4 \mathrm{Jd}$ ). No analysis of the areal share by dominant species was made. The type of forest habitat and soil sub-type for sub-compartments were taken from the forest management plan of 2006. The type of bed rock was determined using the geological map of Poland with a scale of 1:200,000 containing information about the stratigraphic structure of Earth's crust, i.e. the kind of rocks that were formed in different geological periods.

Geological cross-sections of Earth's crust are made on the basis of the material taken from boreholes to specify, inter alia, the kind and the sequence of underlying rock layers in the geological horizon. The whole territory of Poland is covered with multi-sheet geological maps. The main map edition covering the whole territory has a scale of 1:50,000. It includes, inter alia, the detailed geological map of Poland under development since 1953. The research area is covered by Starachowice (No. 780) and Sienno (No. 781) map sheets. Because the Sienno sheet is unavailable (currently under development), a 1:200,000 scale geological map of Poland (MGP) without Quaternary bedrock was used in the research.
The study analyses the distribution of fir in all stand layers in accordance with the following methodology. The ratio of the number of stands with fir to the total number of stands in the study area or the number of stands on a given type of the bedrock was calculated for the entire research area and for each type of the bedrock. The number of stands in the study area was 577 . The proportion of fir in the stand is determined by the stand density index. The following stand density index values were assumed: 0.0 (without fir); 0.1 (stand density 0.1 in the upper or lower storey or in the advance growth layer or the occurrence of single or reserved fir trees or the occurrence of fir in the underwood layer); 0.2, 0.3, etc. up to 1.0 according to the forest management plan. Stand density index values were not summed, with the simultaneous occurrence of fir trees in the stand layers. The highest ratio was assumed, regardless of the layer.

Statistical tests and graphs were performed using STATISTICA 8. The dependence of fir occurrence on the underlying bedrock was determined by performing tests of differences between the two indicators of the structure. The significance level $\mathrm{p}$ was calculated, and statistically significant differences were shown (Stanisz 2006).

\section{Results}

In 1941, the area occupied by fir in the lower storey of the stand covered 92.8 ha $(2.76 \%$ of the forest

Table 1. Area of tree species in the first-stand layer according to site types in Iłżecka Forest in 1941

\begin{tabular}{|c|c|c|c|c|c|c|c|c|c|c|c|c|}
\hline \multirow{3}{*}{ Species* } & \multicolumn{12}{|c|}{ Area of tree species in the first stand layer (ha) } \\
\hline & \multicolumn{12}{|c|}{ Site type** } \\
\hline & Bśw & BMśw & $\mathrm{BMw}$ & BMwyżśw & LMśw & LMw & LMwyżśw & Lśw & Lw & $\mathrm{Ol}$ & OlJ & Total \\
\hline So & 29.4 & 294.3 & 15.1 & 32.9 & 2065.9 & 8.1 & 3.7 & 119.7 & 1.7 & 20.1 & & 2590.9 \\
\hline Md & 0.9 & 0.6 & & & 5.7 & & & & & & & 7.1 \\
\hline Św & & 0.1 & & & 6 & & & 0.8 & & & & 6.9 \\
\hline $\mathrm{Jd}$ & & 0.3 & & & 51.8 & & & 40.5 & & 0.3 & & 92.8 \\
\hline $\mathrm{Db}$ & 0.1 & 0.3 & & & 445.2 & & & 3.5 & & & & 449.2 \\
\hline $\mathrm{Brz}$ & & 1.6 & 0.4 & & 105.1 & 1.8 & & 27.1 & 3.4 & 2.8 & & 142.1 \\
\hline Oś & & & & & 19.6 & 0.8 & & 12.2 & & 0.5 & & 33 \\
\hline $\mathrm{Ol}$ & & & & & 7.5 & 3.2 & & & 11.9 & 2.1 & 6.1 & 30.7 \\
\hline $\mathrm{Gb}$ & & & & & 4.1 & & & 8.1 & 12.2 & & & 12.2 \\
\hline Total & 30.4 & 297.3 & 15.5 & 32.9 & 2710.8 & 13.8 & 3.7 & 211.8 & 17 & 25.7 & 6.1 & 3364.9 \\
\hline
\end{tabular}

*Tree species: So - pine, Md - larch, Św - spruce, Jd - fir, Bk - beech, Db - oak, Dbcz - northern red oak, Brz - birch, Os - aspen, Ol - alder, $\mathrm{Gb}$ - hornbeam, Kl - maple, JW - sycamore, Js - ash, Lp - lime, Ak - black locust, Wz - elm

**Site type: Bśw - fresh coniferous forest, BMśw - fresh mixed coniferous forest, BMw - moist mixed coniferous forest, BMwyżśw - fresh upland mixed coniferous forest, LMśw - fresh mixed deciduous forest, LMw - moist mixed deciduous forest, LMwyżśw - fresh upland mixed deciduous forest, Lśw - fresh deciduous forest, Lw - moist deciduous forest, Ol - alder forest, OlJ - alder-ash forest 
Table 2. Area of tree species in the first stand layer according to site types in Iłżecka Forest in 2006 (symbols of tree species and forest site types as in Table 1)

\begin{tabular}{|c|c|c|c|c|c|c|c|c|c|c|c|c|}
\hline \multirow{3}{*}{ Species } & \multicolumn{12}{|c|}{ Area of tree species in the first stand layer (ha) } \\
\hline & \multicolumn{12}{|c|}{ Site type } \\
\hline & Bśw & BMśw & $\mathrm{BMw}$ & BMwyżśw & LMśw & $\mathrm{LMw}$ & LMwyżśw & Lśw & Lw & $\mathrm{Ol}$ & OlJ & Total \\
\hline So & 22.57 & 280.79 & 20.30 & 23.94 & 1874.85 & 11.36 & 10.49 & 56.42 & 3.99 & 0.76 & 1.16 & 2306.61 \\
\hline Md & & 0.31 & & 1.00 & 49.68 & 0.39 & & 5.06 & & & & 56.43 \\
\hline Św & & 0.21 & & & 7.07 & 1.42 & & 0.85 & & 0.13 & & 9.68 \\
\hline $\mathrm{Jd}$ & & 6.17 & & 0.38 & 208.43 & & & 69.26 & 3.36 & 0.26 & & 287.87 \\
\hline Bk & 0.31 & 2.12 & & & 36.90 & & & 3.48 & & & & 42.81 \\
\hline $\mathrm{Db}$ & & 11.84 & & & 396.78 & 1.40 & & 5.42 & & 0.17 & & 415.61 \\
\hline Dbcz & & & & & 2.08 & & & & & & & 2.08 \\
\hline $\mathrm{Brz}$ & 0.23 & 9.73 & 2.32 & & 174.39 & 3.59 & & 20.36 & 1.47 & 0.49 & 0.92 & 213.51 \\
\hline Os & & & & & 0.29 & & & 0.28 & & & & 0.57 \\
\hline $\mathrm{Ol}$ & & & 0.34 & & 1.58 & 10.84 & & & 7.33 & 4.73 & 4.94 & 29.76 \\
\hline $\mathrm{Gb}$ & & & & & 27.78 & & & 18.11 & & & & 45.89 \\
\hline K1 & & & & & & & & 0.06 & & & & 0.06 \\
\hline $\mathrm{JW}_{\mathrm{W}}$ & & & & & 0.69 & 0.39 & & 1.02 & 0.18 & & & 2.28 \\
\hline Js & & & & & & & & 0.13 & 0.18 & 0.13 & & 0.44 \\
\hline Lp & & & & & 0.61 & & & & & & & 0.61 \\
\hline $\mathrm{Ak}$ & & & & & 0.04 & & & & & & & 0.04 \\
\hline $\mathrm{Wz}$ & & & & & 1.16 & & & 0.82 & & & & 1.98 \\
\hline Total & 23.11 & 311.17 & 22.96 & 25.32 & 2782.32 & 29.38 & 10.49 & 181.25 & 16.51 & 6.67 & 7.02 & 3416.20 \\
\hline
\end{tabular}

area in the Iłżecka Forest) (Table 1). It usually occurs in the fresh mixed deciduous forest (LMśw) (51.80 ha) and fresh deciduous forest (Lśw) (40.5 ha) habitats, covering $2 \%$ and $19 \%$ of the habitat area, respectively. In 1941, pine occurred in all forest habitats except for alder-ash forests. Oak was found almost exclusively in the fresh mixed deciduous forest habitat (LMśw) (445.2 ha) and held more than $99 \%$ of the habitat area. The four main forest trees species: pine, oak (pedunculate and sessile), birch and fir occupied $97.3 \%$ of the forest area of the Iłżecka Forest.

After 65 years, in 2006, fir occurred in the investigated area mainly in the habitats of fresh mixed deciduous forests (LMśw) and fresh deciduous forests (Lśw) as well as in small areas of fresh mixed coniferous forests (BMśw), fresh upland mixed coniferous forests (BMwyżśw), moist deciduous forests (Lw) and alder forests (Ol) (Table 2). In the upper storey, fir occupied 287.87 ha $(8.44 \%)$. Fresh mixed deciduous forests (LMśw) covered an area of 208.43 ha (7.5\% of the habitat area) and the fresh deciduous forests (Lśw) -69.26 ha (39\% of the habitat area). In 1941 and 2006, pine was the main forest tree species in the investigated area in the Iłżecka Forest; it dominated in the stands and oc- curred in all forest habitat types. Oak, mostly the sessile oak, was the second largest group of tree species. In the fresh mixed deciduous forest habitat (LMśw), it covered $95.4 \%$ of its total area in the forest. A slight increase was noted in the proportion of oak in the fresh mixed coniferous forest (BMśw). Birch grew in all forest habitats. Hornbeam and aspen stands in the upper storey of the stand occurred in the richest fresh mixed deciduous forest (LMśw) and fresh deciduous forest (Lśw) habitats. The presence of sycamore in fertile and moist deciduous forest habitats was seen in the year 2006, while in 1941, sycamore was absent in the upper storey of the stand.

In the upper storey of the stand, fir occurred on podzolic soils B, muck dystric gleysols Bgms, typical dystric gleysols Gw, peat-moorsh soils Mt, typical pseudogley soil Ogw, brown rusty soils RDb and typical rusty soils RDw (Table 3). Most frequently, it grew on typical pseudogley soils (44\% of its share), brown rusty soils (35\%) and typical rusty soils (18\%). On the residue remaining soil subtypes, it appeared occasionally (3\%).

Figure 1 illustrates the proportion of fir in the stands under study in 2006 using a stand density index. Fir was absent in $46 \%$ of the total number of stands. The proportion of fir in the stands usually oscillated around $10 \%$ (27\% of 


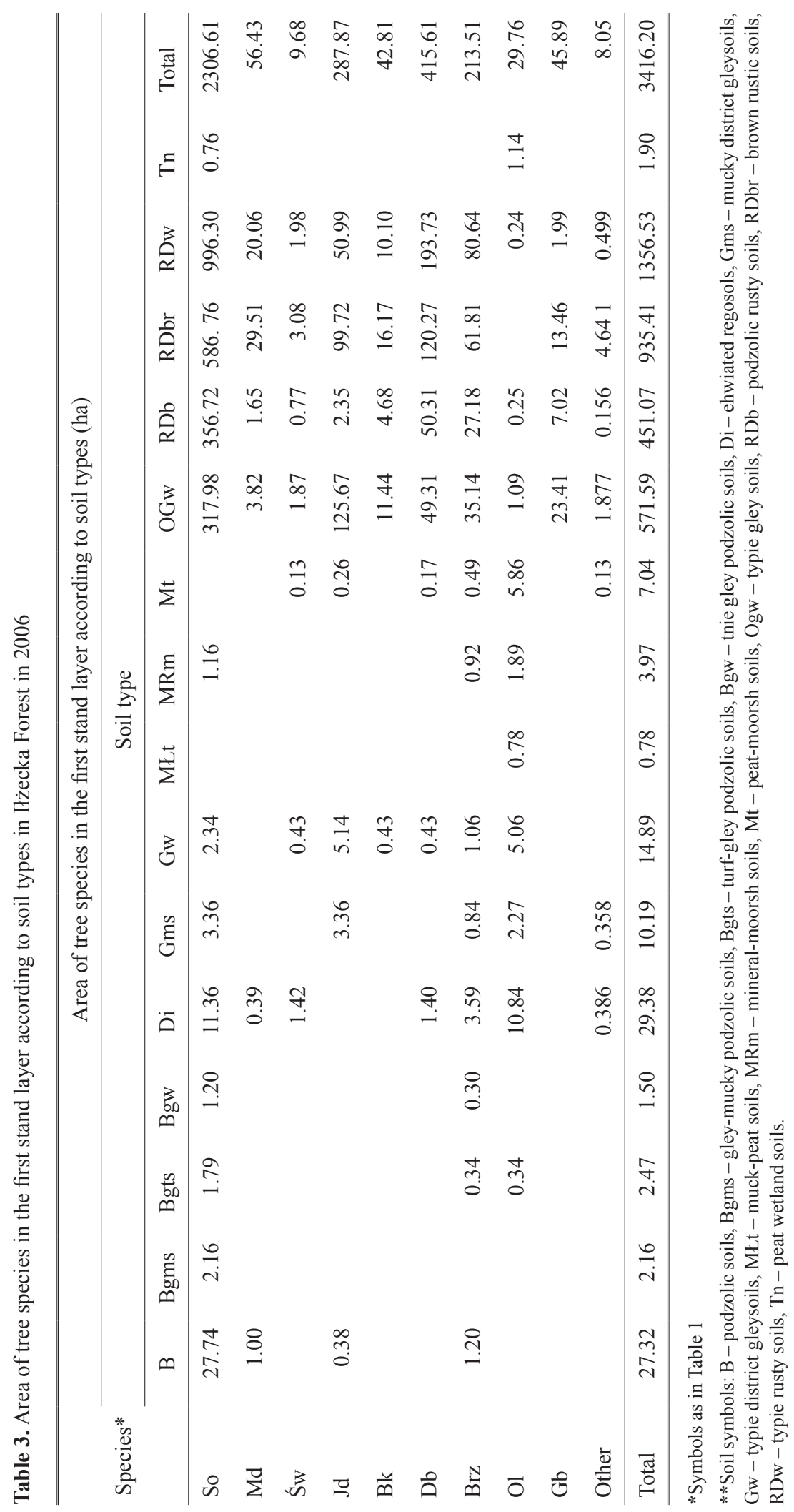


stands). Stands with a $70 \%$ and higher share of fir accounted for $11 \%$, and stands with a $20-60 \%$ share of fir accounted for $16 \%$. Pure fir stands accounted for $5 \%$ of stands.

In 2006 , the majority of fir stands, more than $80 \%$ of all stands occurred in the upper part of the Middle Jurassic bedrock (Upper Bajocian, Bathonian, Callovian), $65 \%$ in the lower part of the Middle Jurassic bedrock (Aalenian, Lower Bajocian) and 55\% on the Tertiary deposits. The smallest share of fir stands was found on the Upper Jurassic bedrock (32\%). In 1941, fir in the upper storey of stands occurred in the upper part of the Middle Jurassic bedrock accounting for $20 \%$, in the lower part of the Middle Jurassic bedrock accounting for $14 \%$, on the Tertiary bedrock - for $10 \%$ and on the Upper Jurassic bedrock - for $1 \%$ of all stands depending on bedrock type. In 2006, the number of stands with fir was similar to the number of stands in 1941 for each bedrock type.

\section{Discussion}

During the years 1932-2005, the share of pine in the upper storey of the studied stands decreased by $9 \%$ (232 ha) as a result of natural processes and planned silvicultural operations supporting the appearance and

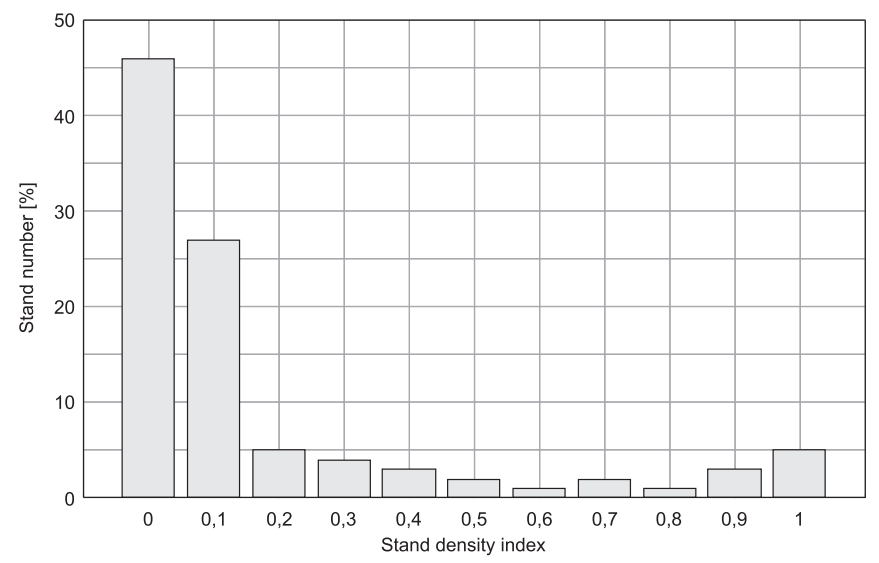

Figure 1. Share of fir in the studied stands according to the stand density in 2006. Notes: 0 - without fir; $0.1,0.2, \ldots, 1-$ share of fir in a stand, $10 \% ; 20 \%,, 100 \%$, respectively

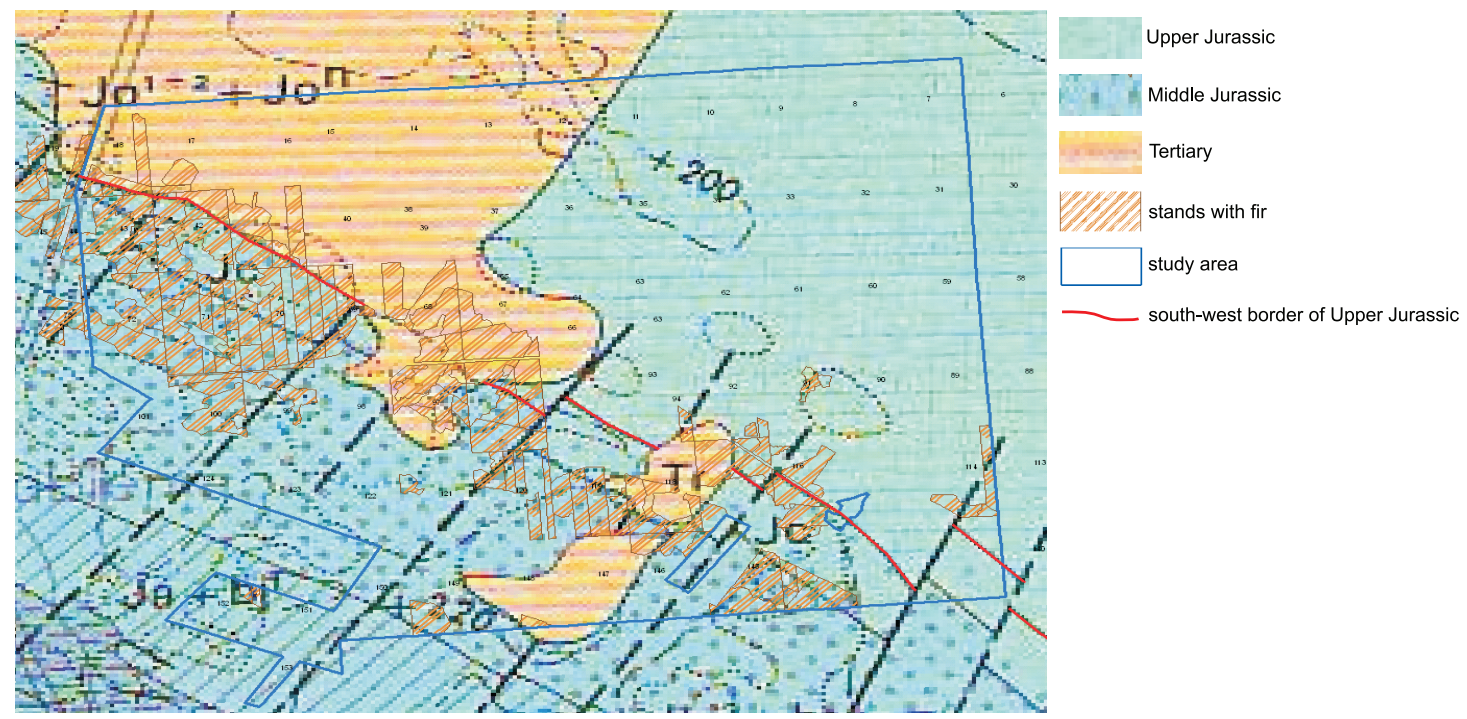

Figure 1. Stands with silver fir in the first layer on the geological map of Poland. 
Table 4. Test of differences results between two structure indices for fir occurrence in stands of different geological base

\begin{tabular}{ccc}
\hline \multicolumn{3}{c}{ Test of differences } \\
\hline Jg. $=32$ & $N$ & $p$ \\
Trz. $=55$ & Jg. $=177$ & 0.0000 \\
\hline Jg. $=32$ & Trz. $=162$ & 0.000 \\
Jś a. $=65$ & Jg. $=177$ & \\
\hline Jg. $=32$ & Jś a. $=189$ & 0.000 \\
Jś b. $=84$ & Jg. $=177$ & 0.281 \\
\hline Trz. $=55$ & Jś b. $=49$ & \\
Jś a. $=65$ & Trz. $=162$ & 0.001 \\
\hline Trz. $=55$ & Jś a. $=189$ & \\
Jś b. $=84$ & Trz. $=162$ & 0.0052 \\
\hline Jś a. $=65$ & Jś b. $=49$ & \\
Jś b. $=84$ & Jś a. $=189$ \\
\hline \hline
\end{tabular}

Notes: $\mathrm{N}$ - number of stands; \% - percentage of stands with fir, Trz. - Tertiary, Jg. - Upper Jurassic, Jś a. -Middle Jurassic, lower part, Jś b. -Middle Jurassic, upper part, $p$ - probability.

development of spontaneous natural regeneration of fir. Fir replaced pine, increasing its share by $243 \%$ (204 ha). In suitable environmental conditions, fir becomes one of the main forest tree species. The secondary succession of fir plays a significant role for both nature and economy. It determines the direction of natural changes and should be used in silvicultural management. It results in the restoration of species composition of stands.

In 1930, Professor Stanisław Sokołowski wrote: 'A clear tendency has recently been observed in Polish forestry to restore the lost significance of fir. This tendency is worth approval and should be given strong support' (Niemtur et al. 2007). This clear message of Professor Sokołowski, a pioneer of Polish forestry, is confirmed in the above research results.

The increase in the area of fir in the examined stands is associated with an increase in the proportion of hornbeam in all stand layers. In the discussed fragment of the Ilżecka Forest, this is particularly noticeable in the Lśw forest habitat where hornbeam held a dominant position in the advance growth layer and young generation of trees (78\% of the total number of trees in this regeneration phase) (Bis 2010). Hornbeam is also quite abundant in the LMśw forest habitat in the regeneration and lower layers of the stand. The increasing proportion of hornbeam in the stands of the Iłżecka Forest may be the result of progressive eutro- phication of habitats. Sokołowski (2006) indicates that recent decades have seen a trend to increase the proportion of hornbeam in the species composition of stands. Hornbeam occupies poorer habitats forming a dense canopy in the lower stand layer. In consequence, the strong shading of the bottom of the forest prevents natural regeneration of other species. The expansion of hornbeam and the related formation of hornbeam stands eliminating the oligotrophic species of herbaceous layer and natural regeneration of more light-demanding tree species than hornbeam and lime was also observed in the Białowieża Forest (Sokołowski 1999; Paluch 2001; Keczyński 2007) and Kozienicka Forest (Orzechowski 2002).

The distribution of fir stands in the area of research is uneven. In the studied stands, also stands without fir can be found in the LMśw and Lśw forest habitats. In the studies on the environmental factors influencing the health status and growth of fir stands in the lowlands and in the mountains of Poland, soil subtype is of great importance. Fir in the Iłżecka Forest occurs primarily on gley and rusty soils. The proportion of fir in the stand depends largely on the soil environment (Adamczyk, Januszek 1977); soil moisture is one of the major environmental factors determining the growth of fir stands (Januszek 2003).

The research shows that bedrock has a significant effect on the distribution of fir in the entire study area. Based on the analysis of fir distribution in relation to the type of bedrock, one can assume that it has a decisive effect on fir distribution in the study area. This is probably the least recognised and described environmental factor affecting fir occurrence in the Iłżecka Forest. The type of bedrock is thought by many researchers to be an essential element of the classification of habitats, especially in the mountain conditions (Chodzicki 1947; Alexandrowicz 1957; Bernadzki 1963; Mroczkiewicz, Trampler 1964). The presented results permit to consider this environmental factor important for fir distribution also in the lowland conditions.

The dependence of fir distribution on geological bedrock can be attributed to the influence of the type of rock conditioning soil moisture content. It has been found that the occurrence of fir is related to the Middle Jurassic bedrock, which is made up of hard permeable clayey rocks. Most soils in this area are developed from Quaternary sediments overlying the Middle Jurassic rocks slowing down the permeability of water into the soil profile, maintain stable moisture conditions and suit fir growth. The average annual rainfall in the Iłżecka Forest is between 570 and $650 \mathrm{~mm}$, which is the minimum value range for fir. A small amount of rainfall can be balanced by corresponding bedrock properties. 
Adaptation of fir to such conditions can also result from physiological variability (ecotype). With a small amount of precipitation within its range, fir retains the ability to grow on impermeable clayey soils having a higher moisture content than permeable soils. Fir stands, with a good natural renewal, occur on cohesive soils made of heavy silty clays, with a large admixture of floatable fractions at the colloidal clay bottom, high and stable moisture content, frequently with the gley horizon. Fir is insensitive to the low soil aeration, while it is extremely sensitive to changes in soil moisture content (Jaworski, Zarzycki 1983).

The eastern part of the Iłżecka Forest is the area of the Upper Jurassic where fir does not grow. The sandy loam or loamy sand soils in this area admixed with weathered limestone, thick, warm and located on permeable limestone ground are a suitable habitat for pine, pine-oak and oak forests but not for fir. The forest habitat type in the Iłżecka Forest does not provide a sufficient basis for silvicultural planning. Silvicultural planning requires employment of the lower level units of forest habitat classification. The bedrock was considered an important element of habitat classification already in the middle of the past century. Studying the relationships between fir distribution and bedrock allows better recognition of the natural potential of forest habitats in the Iłżecka Forest. This allows distinguishing the lower level units of forest typology within the forest habitat type, creating the rational foundations for a precise determination of the target species composition of stands influenced by local geological conditions. Natural foundations for silvicultural planning can be better recognised using the geological map of Poland.

\section{Summary}

The area of the Mid-Polish Trough characterised by a relatively large thickness of Mesozoic sediments, much thicker than in other regions of Poland, the bedrock forming the floor of younger Quaternary bedrocks may condition the distribution of fir within its natural range. This thesis requires verification and further research.

\section{Conclusions}

Fir in the Iłżecka Forest is an important forest-forming tree species in LMśw and Lśw, whereas in the mixed coniferous forests it is merely an admixture species.

The distribution of fir in the Iłżecka Forest depends on soil subtype. Fir occurs on typical pseudogley soils as well as rusty brown and typical rusty brown soils.
The distribution of fir stands in the Forest Iłżecka depends on bedrock. Fir occurs on the Middle Jurassic clays that stabilise soil moisture conditions, alleviating the deficit of atmospheric precipitation.

To rationally differentiate the target production forest types in the Iłżecka Forest, the sub-units of forest habitat types should be distinguished for LMśw and Lśw forest habitats depending on the type of Mesozoic bedrock, specifically:

- LMśw habitat: a - a variant with fir, pine and oak (Middle and Lower Jurassic bedrock) and $\mathrm{b}-\mathrm{a}$ variant with pine and oak (Upper Jurassic geological bedrock).

- - habitat Lśw: a - a variant with fir and beech (Middle and Lower Jurassic bedrock) and $b-a$ variant with oak and pine (Upper Jurassic bedrock).

The proposed variants of stand species compositions allow more accurate adjustment of species composition to the habitat conditions in this area.

\section{Acknowledgements}

We thank the Starachowice Forest District staff for their assistance in collecting materials for this research project.

\section{References}

Adamczyk B., Januszek K. 1977. Odnowienie samosiewne jodły w charakterystycznych zbiorowiskach leśnych terenów górskich. Cz. 1. Charakterystyka gleb. Dokumentacja. Kraków, Akademia Rolnicza, Zespół Gleboznawstwa Leśnego IHL.

Alexandrowicz B. 1957. Typy lasu Wielkopolskiego Parku Narodowego [Forest types in the Wielkopolska National Park]. Sylwan, 5: 33-45.

Bernadzki E. 1963. Typy siedliskowe lasu na utworach godulskich w Beskidzie Śląskim [The site types of forest on the formation of Godula in the Silesian Beskid]. Prace Instytutu Badawczego Leśnictwa, 262: 119-195.

Bernadzki E. 1967. Badania nad wyborem rębni w drzewostanach jodłowych w Górach Świętokrzyskich. Prace Instytutu Badawczego Leśnictwa, 329.

Bernadzki E. 1974. Badania nad wykorzystaniem udoskonalonej klasyfikacji siedlisk do planowania hodowlanego (na przykładzie Dzielnicy Gór Świętokrzyskich). Prace Instytutu Badawczego Leśnictwa, 461: 1-81.

Bernadzki E., Szeremetti B. 1976. Okres odnowienia jodty na siedlisku lasu mieszanego w Górach Świętokrzyskich [Period of fir regeneration on the site of mixed deciduous forest in Świętokrzyskie Mts.]. Sylwan, 3: 47-56.

Bis R. 2010. Dynamika występowania jodły pospolitej (Abies alba Mill.) w południowo-wschodniej części Puszczy Iłżeckiej w okresie 1932-2005. Rozprawa doktorska. Maszynopis. Warszawa, SGGW. 
Chodzicki E. 1947. Krainy, dzielnice i obwody leśno-fizjograficzne południowo-zachodniej Polski. Leśno-fizjograficzne rozczłonkowanie lasów Dyrekcji Krakowskiej [Physiographic forest regions, divisions and sections of the South-Western Poland]. Sylwan, 1: 32-77.

Dolnicki A., Kuchciński L. 2003. Wstępne badania nad mrozoodpornością jodły pospolitej (Abies alba Mill.) w Górach Świętokrzyskich [Preliminary studies on frost - hardiness in silver fir (Abies alba Mill.) from the Holy Cross Mountains]. Sylwan, 8: 84-93.

Graniczny S., Dobrowolska D. 1990. Wstępna ocena stanu hodowlanego i zdrowotnego drzewostanów z udziałem jodły na wybranych powierzchniach badawczych Świętokrzyskiego Parku Narodowego i Puszczy Świętokrzyskiej [Introductory assessment of the cultivation and salubrity state of tree-stand with the participation of Fir-trees on selected research areas of the Świętokrzyski National Park and Świętokrzyski Forest]. Rocznik Świętokrzyski, 17: 29-45.

Feliksik E. 1986. Badania dendroklimatologiczne nad jodłą (Abies alba Mill.) z obszarów górskich. Sprawozdanie z realizacji zadania 03.06.03. Kraków, Akademia Rolnicza, Pracownia Klimatologii Leśnej.

Feliksik E., Wilczyński S., Podlaski R. 2000. Wpływ warunków termiczno-pluwialnych na wielkość przyrostów radialnych sosny (Pinus sylvestris L.), jodły (Abies alba Mill.) i buka ( $\mathrm{Fa}$ gus sylvatica L.) z Świętokrzyskiego Parku Narodowego [The influence of air temperature and atmospheric precipitation on the radial increments of pine (Pinus sylvestris L.), fir (Abies alba Mill.) and beech (Fagus sylvatica L.) from Świetokrzyski National Park]. Sylwan, 9: 53-64.

Januszek K. 2003. Badanie czynników ekologicznych na stan zdrowotny i kondycję wzrostową drzewostanów jodłowych na nizinach i w górach. Kraków, Akademia Rolnicza im. H. Kołłątaja. Pracownia Gleboznawstwa Leśnego. Zakład Ekologii Lasu.

Jaworski A., Zarzycki K. 1983. Ekologia, in: Jodła pospolita Abies alba Mill. Nasze drzewa leśne. (ed. S. Białobok). Vol. 4. Warszawa, PWN, 317-430. ISBN 8301040289.

Keczyński A. 2007. Regeneracja grądu Tilio-Carpinetum Tracz. w następstwie dawnego użytkowania lasu w Białowieskim Parku Narodowym [Regeneration of Tillio-Capinetum hornbeam forest (Tracz, 1962) as a follow-up of forest utilisation in the Białowieża National Park]. Sylwan, 1: 58-65.

Kondracki J. 2000. Geografia regionalna Polski. Warszawa, PWN. ISBN8301130504.

Królicki A. 2004. Zróżnicowanie właściwości technicznych drewna Abies alba L. i kształtowanie się rynku drewna jodłowego w Polsce. Rozprawa doktorska. Maszynopis. Warszawa, Szkoła Główna Gospodarstwa Wiejskiego, Wydział Leśny, Katedra Użytkowania Lasu.

Mroczkiewicz L., Trampler T. 1964. Typy siedliskowe lasu w Polsce [Forest site types in Poland]. Prace Instytutu Badawczego Leśnictwa, 250: 1-160.

Niemtur S., Zawada J., Ambroży S. 2007. Charakterystyka wybranych drzewostanów jodłowych o złożonej strukturze na obszarze RDLP Katowice i Krosno [Characteristic of silver fir stands (Abies alba Mill.) with composite structure on the area of Krosno and Katowice Dicrectorate of State Forests]. Sylwan, 2: 7-18.

ORWLP. 2004. Siedliskowe podstawy hodowli lasu. Bedoń, Ośrodek Rozwojowo-Wdrożeniowy Lasów Państwowych w Bedoniu.

Orzechowski M. 2002. Przemiany zbiorowisk leśnych Puszczy Kozienickiej w II połowie XX wieku i ich gospodarcze konsekwencje. Rozprawa doktorska. Warszawa, SGGW.

Paluch R. 2001. Zmiany zbiorowisk roślinnych i typów siedlisk w drzewostanach naturalnych Białowieskiego Parku Narodowego. Sylwan, 10: 73-81.

PGLLP 2008. Raport o stanie lasów w Polsce. Warszawa, Centrum Informacyjne Lasów Państwowych.

Podlaski R. 2000. Ocena kondycji jodły (Abies alba Mill.), buka (Fagus silvatica L.), i sosny (Pinus sylvestris L.) starszej generacji za pomocą wskaźnika żywotności, w wybranych drzewostanach Świętokrzyskiego Parku Narodowego [An assessment of the health condition of silver fir (Abies alba Mill.), European beech (Fagus sylvatica L.) and Scots pine (Pinus sylvestris L.) of the older generation using the vitality index, in selected stands of the Świetokrzyski National Park]. Sylwan, 6: 83-88.

Podlaski R. 2001. Wpływ wybranych właściwości gleb na żywotność jodły (Abies alba Mill.), buka (Fagus silvatica L., i sosny (Pinus sylvestris L.) w Świętokrzyskim Parku Narodowym [The effect of some soil properties on vitality of the silver fir (Abies alba Mill.), the European beech (Fagus sylvatica L.), and the Scots pine (Pinus sylvestris L.) in the Świętokrzyski National Park]. Sylwan, 6: 79-86.

Podlaski R. 2008. Dynamics in Central European near-natural Abies-Fagus forests: Does the mosaic-cycle approach pro-vide an appropriate model? Journal of Vegetation Science,19: 173-182.

Sokołowski A. W. 1999. Kierunki naturalnej sukcesji zbiorowisk leśnych jako podstawa postępowania hodowlanego w Leśnym Kompleksie Promocyjnym Puszcza Białowieska. Prace Instytutu Badawczego Leśnictwa, Seria B, 36: 5-25.

Sokołowski A. W. 2006. Lasy północno-wschodniej Polski. Warszawa, Centrum Informacyjne Lasów Państwowych. ISBN 8389744406.

Stanisz A. 2006. Przystępny kurs statystyki z zastosowaniem STATISTICA PL na przykładach z medycyny. Kraków, StatSoft.

Szafer W. 1959. Szata roślinna Polski. Warszawa, PWN. Srodoń A. 1983. Jodła pospolita w historii naszych lasów, in: Jodła pospolita Abies alba Mill. Nasze drzewa leśne (red. S. Białobok), Vol. 4. Warszawa-Poznań, PWN, p. 9-39. ISBN 8301040289.

Wiąckowski S. 1980. Mikrobiologiczne zwalczanie wyłogówki jedlineczki - Choristoneura murinana Hb. (Lepido-ptera, Tortricidae) w Górach Świętokrzyskich [Microbiological control of Choristoneura murinana Hb. (Lepido-ptera, Tortricidae) in Świętokrzyskie Mountains]. Rocznik Świętokrzyski, 7: 171-175. Woś A. 1999. Klimat Polski. Warszwa, PWN. ISBN 8301127805.

Zaręba R. 1973. Zmiany składu gatunkowego drzewostanów Puszczy Iłżeckiej na podstawie inwentaryzacji z lat 1789, 1885 i 1961. Zeszyty Naukowe Akademii Rolniczej w Warszawie Seria Historyczna, 10. 